\title{
Verpleegkundigen in de thuiszorg houden zich goed staande in de veranderende zorg
}

De mensen die thuiszorg nodig hebben worden ouder, zijn vaker chronisch ziek en willen de regie houden in hun leven.

Verpleegkundigen voelen zich competent voor deze veranderende zorg. Wel is extra aandacht nodig voor de zorg voor cliënten met complexe zorgvragen. Dit blijkt uit een peiling onder de verpleegkundigen van het landelijke NIVEL Panel Verpleging \& Verzorging.

Kim de Groot, Anke de Veer, Anneke Francke

Het zijn roerige tijden in de thuiszorg. De grootschalige hervorming van langdurige zorg die vanaf 1 januari 2015 is ingezet zorgt voor veel veranderingen in het werk van de verpleegkundigen in de thuiszorg. Dit is terug te zien in de indicatiestellingen, de komst van sociale wijkteams en de intensieve contacten met gemeenten en andere professionals op het gebied van zorg, wonen en welzijn. Daarnaast verandert de cliëntenpopulatie. Zo spelen de vergrijzing en toename van het aantal chronisch zieken een rol en wordt verondersteld dat steeds meer cliënten eigen regie en zelfredzaamheid belangrijk vinden (Doekhie e.a., 2014). Wat doen deze veranderingen met de verpleegkundigen in de thuiszorg?

\section{Verpleegkundigen kunnen veranderingen goed aan \\ Uit de peiling (Maurits e.a., 2016) blijkt dat de meeste verpleegkundigen zich competent voelen om met de veranderin- gen in zorgvragen om te gaan. Veruit de meeste verpleegkundigen voelen zich competent om met cliënten om te gaan}

van zeer hoge leeftijd (93\%) en met cliënten met chronische ziekten (84\%). Ook in de omgang met cliënten die eigen regie en zelfredzaamheid belangrijk vinden ervaren de verpleegkundigen veelal geen enkel probleem: respectievelijk 89\% en 91\% voelt zichzelf op deze vlakken in hoge mate of volledig competent.
Toename complexe zorgvragen

In de afgelopen twee jaar is in de thuiszorg vooral de complexiteit van de zorgvragen veranderd. Complexe zorgvragen strekken zich uit over verschillende domeinen, bijvoorbeeld lichamelijk, psychisch en sociaal gebied (zie kader). Drie kwart van de verpleegkundigen in de thuiszorg (74\%) signaleert een toename van cliënten met complexe zorgvragen. De verpleegkundigen hebben wat meer moeite met deze cliënten. Een ruime helft (53\%) van de verpleegkundigen voelt zich in hoge mate of volledig competent om met deze cliënten om te gaan. Bijna de helft voelt zich enigszins tot redelijk competent. Hoe zou dit komen?

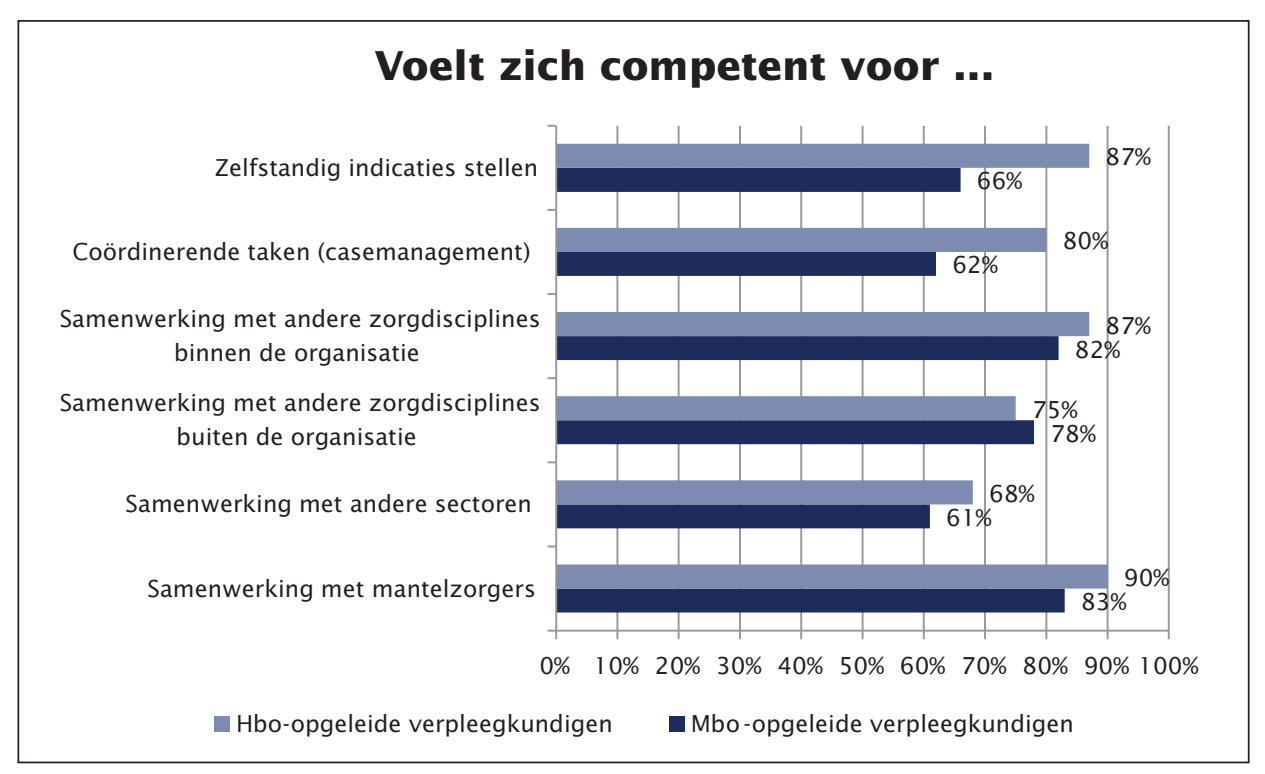

Figuur 1. Percentage verpleegkundigen dat zich in hoge mate of volledig competent voelt om genoemde taken uit te voeren. 


\section{VOORBEELD VAN EEN COMPLEXE ZORGVRAAG}

Meneer De Vries komt naar huis na een ziekenhuisopname vanwege een delier als gevolg van een urineweginfectie. Meneer was al bekend met thuiszorg voor hulp bij medicatie-inname gezien zijn vergeetachtigheid door de ziekte van Alzheimer. Meneer is lichamelijk erg achteruit gegaan tijdens de ziekenhuisopname. Hij is bedlegerig, incontinent van urine en heeft een decubituswond op zijn stuit. Meneer is daarnaast nog erg verward. Hij woont samen met zijn partner die tijdens zijn ziekenhuisopname een psychose en een reuma-aanval heeft gehad. Gezien de kwetsbare thuissituatie heeft het ziekenhuis een verpleeghuisopname voor meneer geadviseerd. Familie heeft toch besloten dat meneer naar huis gaat. De kinderen wonen ver weg en kunnen alleen in het weekend naar hun ouders komen.

\section{Vraag naar andere verpleeg- kundige competenties}

Cliënten met complexe zorgvragen doen een extra beroep op verpleegkundige competenties om zelfstandig indicaties te stellen, coördinerende taken uit te voeren en samen te werken met anderen. Vanuit de spilfunctie die de verpleegkundigen in de thuiszorg hebben zijn zij degene die schakel zijn tussen de cliënt, de mantelzorgers en alle betrokken professionals. Bij complexe zorgvragen is deze samenwerking met mantelzorgers en betrokken professionals van groot belang om de gezondheid en het welzijn van de cliënt in stand te houden. Daarnaast zijn ook het uitvoeren van coördinerende taken (casemanagement) en het zelfstandig indiceren van zorg van belang. De complexe zorgvragen benadrukken het belang van deze taken extra. Verpleegkundigen voelen zich in het algemeen competent om eerdergenoemde taken uit te voeren (figuur 1). Ruim driekwart van de verpleegkundigen voelt zich competent om zelfstandig een indicatie te stellen en de meesten voelen zich ook competent om coördinerende taken uit te voeren. Samenwerking met andere zorgdisciplines gaat de meeste verpleegkundigen ook goed af. Samenwerking met pro- fessionals uit sectoren als wonen en welzijn vinden de verpleegkundigen wat lastiger.

\section{Hbo-opgeleide en mbo-op- geleide verpleegkundigen}

Er is echter wel een verschil zichtbaar tussen de hbo-opgeleide en mbo-opgeleide verpleegkundigen. Hbo-opgeleide verpleegkundigen voelen zich vaker competent voor het zelfstandig stellen van indicaties in vergelijking met mbo-opgeleide verpleegkundigen (figuur 1). Ook in het uitvoeren van coördinerende taken is een duidelijk verschil zichtbaar: hbo-opgeleide verpleegkundigen voelen zich vaker in hoge mate of volledig competent. Dit komt overeen met het spin-in-het-web-zijn, wat volgens het beroepsprofiel van de wijkverpleegkundigen vooral is weggelegd voor de hbo-opgeleide verpleegkundigen (de Bont e.a., 2012). In de samenwerking met anderen is geen duidelijk verschil zichtbaar tussen de hbo-opgeleide en mbo-opgeleide verpleegkundigen (figuur 1).

\section{Ondersteuning nodig}

Door de hervormingen in de zorg moeten verpleegkundigen zich een aantal competenties meer eigen maken. Ruim de helft van de verpleegkundigen (53\%) geeft dan ook aan meer behoefte te hebben aan 'regelmatige casuïstiekbespreking en/of intervisiebijeenkomst'en. In deze besprekingen kunnen verpleegkundigen leren van elkaars ervaringen. Ruim driekwart van de verpleegkundigen (79\%) geeft aan ondersteuning te ervaren doordat zij advies kunnen inwinnen bij deskundigen of adviseurs. Het is belangrijk dat thuiszorgorganisaties hun verpleegkundigen blijven ondersteunen bij de complexe zorgvragen.

\section{Noot}

De informatie uit dit artikel is gebaseerd op een vragenlijst ingevuld door 1135 deelnemers van het NIVEL Panel Verpleging \& Verzorging, waarvan 202 hbo- of mbo-opgeleide verpleegkundigen werkzaam in de thuiszorg (respons 60\%).

\section{Referenties}

Bont, M. de, Haaren, E. van, Rosendal, H. \& Wigboldus, M. (2012). Expertisegebied wijkverpleegkundige. V\&VN, Utrecht

Doekhie K., Veer A.J.E. de, Rademakers J.J.D.J.M., Schellevis F.G., Francke A.L. (2014). Ouderen van de toekomst. Verschillen in de wensen en mogelijkheden voor wonen, welzijn en zorg. Overzichtstudie. NIVEL, Utrecht

Maurits, E.E.M., Veer, A.J.E. de \& Francke, A.L. (2016). Inspelen op veranderingen in de zorg: Ervaringen van verpleegkundigen, verzorgenden, begeleiders en praktijkondersteuners. NIVEL, Utrecht

\section{Over de auteurs}

Kim de Groot, onderzoeker bij het NIVEL in Utrecht en verpleegkundige bij Thebe Wijkverpleging.

Anke de Veer, senior onderzoeker bij het NIVEL in Utrecht.

Anneke Francke, programmaleider bij het NIVEL in Utrecht en bijzonder hoogleraar Verpleging en verzorging in laatste levensfase bij de afdeling Sociale Geneeskunde, EMCO+/ VUmc, Amsterdam. 